\title{
Volatile Components in Protoplasts Isolated from the Marine Brown Alga Dictyopteris prolifera (Dictyotales)
}

\author{
Taichiro FujImurA*, Tetsuo KAWAI*, Tadahiko KajIWARA** and Yuzaburo IshidA*** \\ *Research Laboratories, Shiono Koryo Kaisha, Ltd., 5-17-75 \\ Niitaka, Yodogawa-ku, Osaka, 532 Japan \\ **Department of Biological Chemistry, Faculty of Agriculture, \\ Yamaguchi University, Yoshida, Yamaguchi, 753 Japan \\ ***Department of Fisheries, Faculty of Agriculture, Kyoto University, \\ Oiwake-cho, Kitashirakawa, Sakyo-ku, Kyoto, 606 Japan
}

(Received April 22, 1993)

(Accepted December 6, 1993)

The volatile compounds released from protoplasts of Dictyopteris prolifera were extracted by a closed looping head space (CLHS) procedure. The volatile compounds in the extract were identified by GC and GC-MS. The major characteristic volatile compounds in both the protoplast and the intact plant, were dictyopterenes. Dipropyl disulfide was detected only in the protoplast, whereas cubenol was detected only in the intact plant. These volatile compounds were shown to be produced by the algal enzyme and not by attached bacteria or other epiphytes and then released into Provasoli's enriched seawater modification (PESI) medium. This suggests that a protoplast preparation is a useful tool for research of volatile compounds and their biogeneses in marine algae.

\section{Introduction}

Many marine algae are known to produce a wide variety of chemical compounds, some of which have important biological and pharamaceutical application ${ }^{1-6)}$. For example, dimethyl sulfide which has "seashore smell" is produced by several kinds of multicellular algae ${ }^{7,8)}$ and unicellular algae ${ }^{9)}$. The odor of Dictyopteris species can frequently be detected in the air around beaches. Known as limu lipoa (seaweed gathered from the deep) in Hawaii, the freshly chopped seaweed is used as a condiment with raw fish and othter foods ${ }^{10)}$. The characteristic odoriferous non-isoprenoid $\mathrm{C}_{11}$ hydrocarbons, namely dictyopterenes were isolated as "ocean smell" from the Hawaiian D. plagiogramma and D. australis ${ }^{11)}$. Some $\mathrm{C}_{11}$ hydrocarbons are sexual pheromones such as male gamete-attracting substances of the odoriferous oil in the marine brown algae ${ }^{12)}$. The Caribbean D. delicatula also produces the chemical compounds that deter feeding by reef fishes and amphipods ${ }^{13)}$. The occurrence of the dictyopterenes has been confirmed in the essential oil of the Japanese $D$. prolifera ${ }^{14)}$.

Recently, there has been active study of the plant biotechnology using higher plant tissue culture and cell culture for developing valuable commercial compounds such as medicines, foods, cosmetics, flavors, fragrances and vitamins, which are mainly secondary metabolites and alkaloids, pigments, terpenoids, steroids, oils and fats ${ }^{15-17}$. These techniques are important tools for production of commercially useful substances as well as for physiologically and morphologically basic researches. Whereas few papers have been published on this subject for the development of valuable substances 
or the production of secondary metabolites in seaweed tissue culture and cell technology ${ }^{18,19)}$ many have been written on the improvement of the breed for somatic hybridization in edible seaweeds.

Due to living in a marine environment seaweeds in general have adhesive and symbiotic relationships to various epiphytes and becteria. Thus, care must be taken when determining the origins of trace components (bioactive compounds, volatile compounds etc.) extracted from seaweeds. We reported the production of long chain aldehydes as characteristic flavor compounds by plants that regenerated from protoplasts of the marine green alga Ulva pertus $a^{18)}$ and their production of the higher yields by immobilized-living cells ${ }^{19}$. However, no one has reported on the marine brown algae for the production of useful secondary metabolites using seaweed biotechnology.

In the present report, the production of volatile compounds released from living protoplasts of the marine brown alga $D$. prolifera during incubation under sterile conditions was examined by a closed looping head space (CLHS) technique.

\section{Materials and Methods}

\section{Plant material}

D. prolifera was collected from the Yoshimo coast of Shimonoseki, Yamaguchi, Japan.

\section{Protoplast isolation}

The protoplasts were isolated according to the method described previously ${ }^{20)}$. The protoplasts were isolated from the thalli of $D$. prolifera using a mixed enzyme solution of the oyster enzyme, the abalone enzyme and commercial enzymes such as Cellulase Onozuka R-10, Macerozyme R-10, Driselase, Bigalase M and Sumizyme X.

\section{Volatile compounds analysis}

The volatile compounds released from living protoplasts and the intact plant of $D$. prolifera were harvested by the CLHS apparatus (Fig. 1) modified technique of Grob and Zürcher ${ }^{21)}$. Prior to use, all parts of the apparatus were autoclaved and air from the pump was sterilized by filtration through a $0.20 \mu \mathrm{m}$ Dismic-25 disposable syringe filter unit (Advantec Toyo Kaisha Ltd., Tokyo, Japan). Then, the apparatus was made up in a clean hood. The compounds from plant materials ( $2 \mathrm{~g}$ fresh weight) in $200 \mathrm{~m} l$ of the antoclaved PESI medium ${ }^{22)}$ were adsorbed onto activated

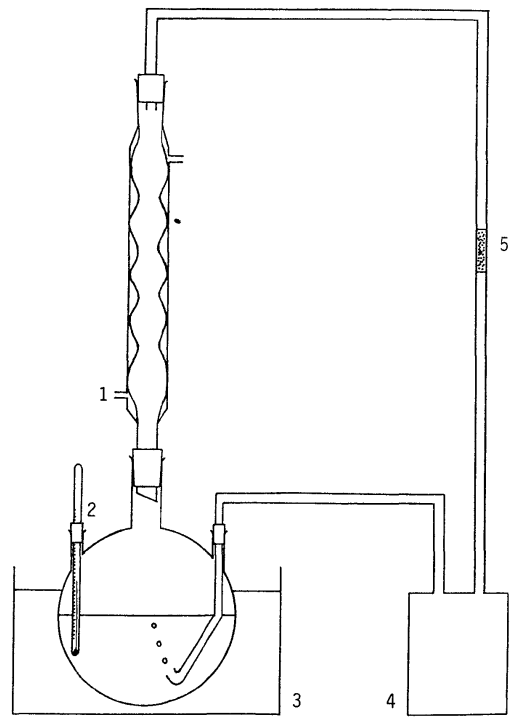

Fig. 1 Closed Looping Head Space apparatus.

1, Cool water; 2, Thermometer; 3, Water bath; 4, Pump; 5, Charcoal. 
charcoal (100 mg, 30/60 mesh, Gasukuro Kogyo Inc., Tokyo, Japan) for $24 \mathrm{hr}$ by the CLHS procedure, while the cultures were incubated at $18-20{ }^{\circ} \mathrm{C}$ under white fluorescent light $(14 \mathrm{hr}$ cycle of 20 $\left.\mu \mathrm{E} \cdot \mathrm{m}^{-2} \cdot \mathrm{s}^{-1}\right)$. The adsorbed compounds were desorbed from the charcoal with dichloromethane (3 $\mathrm{ml}$ ). The desorbed compounds were removed from the solvent by concentration. The resultant solutions (6 $\mu l$ each) were subjected to GC and GC-MS analysis under the conditions described previously ${ }^{18)}$. The volatile compounds were identified by retention indices ${ }^{23)}$ against GC retention time of $\mathrm{C}_{5}-\mathrm{C}_{25} n$-paraffins and by mass spectra of GC-MS using authentic reference standards.

\section{Results}

The volatile compounds released from protoplasts and from the intact plant of D. prolifera were identified by comparing their retention indices on GC and mass spectra of GC-WS with those of authentic specimens. The contents of 10 typical compounds were quantitatively determined in the protoplasts and in the intact plant, respectively (Table 1). The major characteristic of the volatile compounds from the protoplast were various non-isoprenoid $\mathrm{C}_{11}$ hydrocarbons (ca.99\%) such as

Table. 1 Production of volatile compounds in protoplast and in intact plant of Dictyopteris prolifera.

\begin{tabular}{lccc}
\hline \multirow{2}{*}{ Compound } & \multirow{2}{*}{$\mathrm{RI}^{* 1}$} & \multicolumn{2}{c}{ Peak area (\%) } \\
\cline { 3 - 4 } & & Protoplast & Intact plant \\
\hline 3-Butyl-4-vinylcyclopentene (5) & 1063 & 0.93 & 0.94 \\
1-[(1Z)-Hexenyl]-2-vinylcyclopropane $(\mathbf{6})$ & 1081 & tr. $^{* 2}$ & 0.42 \\
Diproply disulfide (10) & 1092 & 0.79 & $-{ }^{* 3}$ \\
Dictyopterene A (1) & 1105 & 19.08 & 18.67 \\
4-[(1E)-Hexenyl]-cyclopentene $(\mathbf{7})$ & 1114 & 3.18 & 6.62 \\
Dictyopterene D' (4) & 1147 & 4.62 & 8.91 \\
6-[(1E)-Butenyl]-1, 4-cycloheptadiene $(\mathbf{8})$ & 1156 & 2.27 & 3.95 \\
Dictyopterene B (2) & 1161 \\
Dictyopterene C' (3) & 1165 & 15.82 & 16.00 \\
Dictyoprolene $(\mathbf{9})$ & 1378 & 9.12 & 10.17 \\
Cubenol (11) & 1642 & - & 3.49 \\
\hline
\end{tabular}

${ }^{* 1}$ Retention index found on DB-1 column. ${ }^{* 2}$ trace $(<0.01 \%)$.

${ }^{* 3}$ Not detected.

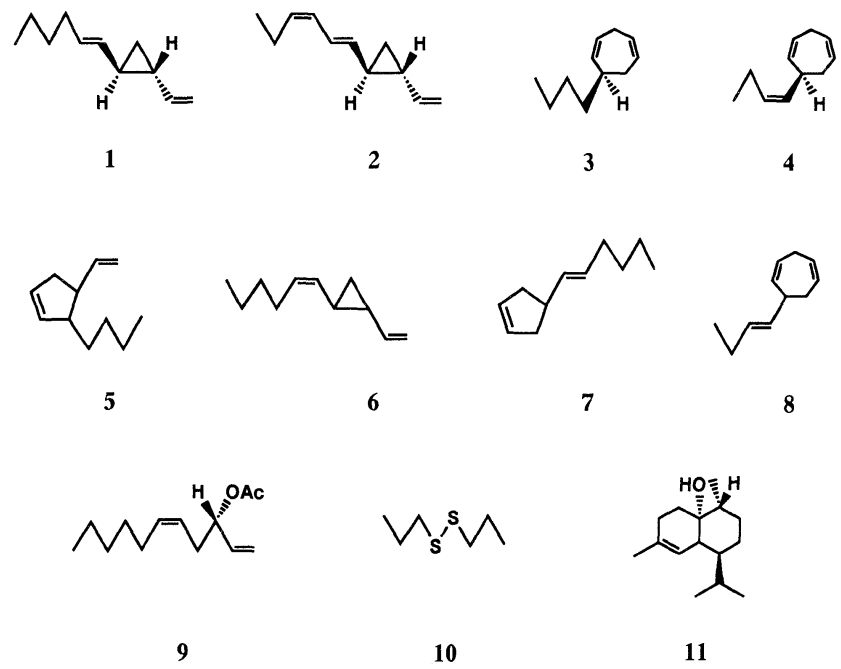

Fig. 2 Structures of volatile compounds. 
dictyopterences which were present in the intact plant. The dictyopterene compounds consisted of dictyopterene A [1-[(1E)-hexenyl]-2-vinylcyclopropane $]$ (Fig. 2-1), dictyopterene B [1-[(1E, 3Z)-hexadienyl]-2-vinylcyclopropane] (2), dictyopterene C' [6-butyl-1, 4-cycloheptadiene] (3) and dictyopterene D' [6-[(1Z)-butenyl]-1,4-cycloheptadiene $]$ (4). Compound 1: RI 1105; MS $m / z(\%) 150\left(\mathrm{M}^{+}, 2\right), 121$ (2), 107 (6), 105 (1), 93 (30), 91 (17), 80 (43), 79 (100), 77 (17), 67 (28), 66 (21), 55 (13), 41 (28). 2: RI 1161; MS m/z (\%) $148\left(\mathrm{M}^{+}, 9\right), 133$ (4), 119 (22), 117 (5), 105 (34), 91 (77), 80 (14), 79 (100), 77 (24), 67 (28), 66 (51), 55 (14), 41 (57). 3: RI 1165; MS m/z(\%) $150\left(\mathrm{M}^{+}\right.$, 10), 121 (4), 107 (12), 93 (65), 91 (28), 80 (52), 79 (100), 77 (28), 67 (21) , 66 (19) , 55 (9) , 41 (28) . 4 : RI 1147; MS $m / z(\%) 148\left(\mathrm{M}^{+}, 9\right), 133$ (4), 119 (23), 117 (5), 105 (34), 91 (76), 80 (17), 79 (100), 77 (22), 67 (28) , 66 (46), 55 (14) , 41 (58). Then, their related compounds such as 3-butyl-4-vinylcyclopentene (5) , 1 - [(1Z) - hexenyl $]$ - 2 - vinylcyclopropane $(6), 4$ - [ $(1 E)$ - hexenyl $]$ - cyclopentene $(7), 6$ [(1E)-butenyl]-1, 4-cycloheptadiene (8) and dictyoprolene (9) were also identified. Compound 6 and 8 are the $(Z)$-isomer of dictyopterene $\mathrm{A}(\mathbf{1})$ and the $(E)$-isomer of dictyopterene D' (4), respectively ${ }^{24)}$. On the other hand, dipropyl disulfide (10) was found in the protoplast, but was not detected in the intact plant. Compound 10: RI 1092; MS $m / z(\%) 152(3), 150\left(\mathrm{M}^{+}, 32\right), 110(2)$, 108 (25), 74 (4), 73 (3), 66 (7), 47 (3), 43 (100), 41 (19). With sesquiterpene, cubenol (11) was found in the intact plant, but not in the protoplast. Compound 11: RI 1642; MS $m / z(\%) 222\left(\mathrm{M}^{+}\right.$, 2), 204 (41), 179 (63), 161 (100), 135 (8), 119 (72), 105 (46), 95 (19), 81 (31), 69 (16), 55 (17), 43 (23).

\section{Discussion}

The dictyopterenes (1-4) have been known as odoriferous constituents responsible for the "ocean smell"11) and sexual pheromones as male gamete-attracting substances in the marine brown algae ${ }^{12)}$. Dictyopterene B (2) and dictyopterene D' (4) were named hormosirene and ectocarpene, respectively, as the sex-pheromones of the brown algae Hormosira banksii and Ectocarpus siliculosus ${ }^{12)}$. In the biogenesis of the brown algal pheromones, ectocarpene was probably derived from the cisdisubstituted isomer of hormosirene ${ }^{25}$. Hormosirene was also isomerized to ectocarpene through thermal Cope rearrangement in the heating condition of GC analysis ${ }^{26)}$. While dipropyl disulfide (10) is the first identification in the marine algae, this sulfur containing organic compound is a major odoriferous component in Allium species such as onion and garlic ${ }^{27)}$. The sulfur compound was also discovered to be a sulfur-containing feeding attractant promoting the striking behavior in goldfish Carassius auratus, carp Cyprinus carpio and crucian carp Carassius auratus cuvieri ${ }^{28)}$. Diisopropyl disulfide related to $\mathbf{1 0}$ was only observed from Microcystis flos-aquae and used as a chemical marker for this species in the aquatic ecosystem because different Microcystis species do not produce the compound ${ }^{29}$. Also, cubenol (11) was for the first time identified in commercial cubeb oil ${ }^{30)}$ and in the wood of Cedrela toona Roxb. ${ }^{31)}$ in higher plants. Further, the cadinane-type sesquiterpene alcohol was found in the brown alga D. divaricata ${ }^{32)}$ and cultured red tide of Gymnodinium nagasakiense ${ }^{33}$. The sesquiterpene alcohol was shown to cause cell-destroying activity against the red tide planktons ${ }^{33)}$.

It was confirmed that dictyopterenes (1-4) and related compounds (5-9) and dipropyl disulfide (10) can be extracted from living protoplasts without any damage and released into a liquid medium under sterile culture conditions in the CLHS apparatus. The results suggest that these intrinsic volatile compounds of $D$. prolifera were produced by the algal enzyme, not by various adhesive organisms such as epiphytes and bacteria. The extraction technique of volatile compounds by the CLHS apparatus may also be used to investigate secretions in very dilute solutions under natural conditions and their metabolism in living organisms. The typical volatile compounds from 
D. prolifera might be biosynthesized through two different metabolic pathways: fatty acids and mevalonic acids. The hypothetic biosynthesis of dictyopterenes via $(3 Z, 6 Z)$-dodecadienoic acid or $(3 Z, 6 Z, 9 Z)$-dodecatrienoic acid from unsaturated fatty acids has been proposed by Boland and Mertes $^{25)}$. On the other hand, cubenol (11) is biosynthesized via $(2 Z, 6 E)$-farnesyl pyrophosphate from mevalonic $\operatorname{acid}^{34)}$. With the protoplast the biosynthetic pathway from fatty acids was operative, while the mevalonic acid pathway to the cadinane-type sesquiterpene did not work. This may be the reason that the mevalonic acid pathway has not led to the sesquiterpene due to the poor accumulation of lower terpenoids in the undifferentiated protoplast. In most undifferentiated plant cell cultures, the production of mono- and sesqui-terpenes in the desired quality and quantity has not been achieved ${ }^{35)}$. The primary reason for the poor accumulation of lower terpenoids in undifferentiated plant cells is considered to be the general absence of specialized secretory vesicles in which lower terpenoids are stored ${ }^{36}$. However, it is possible to utilize immobilization of the protoplast as a technique to enhance the production of desired secretions from D. prolifera. Further, as an example, bioreactors packed with immobilized-living protoplasts are expected to make mass production of the dictyopterenes possible by adding various substrates, e. g., natural and synthetic unsaturated fatty acids. These results indicate that the protoplast isolated from $D$. prolifera might provide a promising source for research on the production and biosynthesis of volatile compounds.

\section{Acknowledgments}

The authors would like to thank Prof. A. Gibor and Dr. M. Polne-Fuller, Marine Biotechnology Center, University of California, Santa Barbara, U. S. A., for helpful suggestion and critical reading of the manuscript.

\section{References}

1) Faulkner, D. J., 1984. Nat. Prod. Rep., $1: 251-280$.

2) Faulkner, D. J., 1986. Nat. Prod. Rep., 3:1-33.

3) Faulkner, D. J., 1987. Nat. Prod. Rep., $4: 539-576$.

4) Faulkner, D. J., 1988. Nat. Prod. Rep., $5:$ 613-663.

5) Faulkner, D. J., 1990. Nat. Prod. Rep., $7: 269-309$.

6) Faulkner, D. J., 1991. Nat. Prod. Rep., 8: 97-147.

7) Haas, P., 1935. Biochem. J., $29: 1297-1299$.

8) Obata, Y., H. Igarashi, K. Matano, 1951. Bull. Japan. Soc. Sci. Fish., 17 : 60-62. (In Japanese with English summary.)

9) Ishida, Y., H. Kadota, 1967. Bull. Japan. Soc. Sci. Fish., 33 : 782-787.

10) Abbott, I. A., 1984. In "Limu. An Ethnobotanical Study of some Hawaiian Seaweeds" 3rd ed., p. 20-23, Pacific Tropical Botanical Garden, Lawai, Kauai, Hawaii.

11) Moore, R. E., 1977. Acc. Chem. Res., $10: 40-47$.

12) Müller, D. G., 1989. In "Algae as Experimental Systems” (eds. by Coleman, A. W., L. J. Goff, J. R. SteinTaylor), p. 201-213, Alan R. Liss, Inc., New York.

13) Hay, M. E., J. E. Duffy, W. Fenical, K. Gustafson, 1988. Mar. Ecol. Prog. Ser., 48 : 185-192.

14) Kajiwara, T., K. Kodama, A. Hatanaka, 1980. Bull. Japan. Soc. Sci. Fish., 46 : 771-775.

15) Neumann, K.-H., W. Barz, E. Reinhard (eds.), 1985. "Primary and Secondary Metabolism of Plant Cell Cultures", p. 1-377, Springer-Verlag, Berlin.

16) Morris, P., A. H. Scragg, A. Stafford, M. W. Fowler (eds.), 1986. "Secondary Metabolism in Plant Cell Cultures", p. 1-262, Cambridge University Press, Cambridge. 
17) Kurz, W. G. W. (ed.), 1989. "Primary and Secondary Metabolism of Plant Cell Cultures II”, p. 1-315, Springer-Verlag, Berlin.

18) Fujimura, T., T. Kawai, M. Shiga, T. Kajiwara, A. Hatanaka, 1990. Phytochemistry, 29 : 745-747.

19) Fujimura, T., T. Kajiwara, 1990. Hydrobiologia, 204/205 : 143-149.

20) Fujimura, T., T. Kawai, T. Kajiwara, Y. Ishida, 1993. Plant Cell Rep. (submitted).

21) Grob, K., F. Zürcher, 1976. J. Chromatogr., $117: 285-294$.

22) Tatewaki, M., 1966. Phycologia, $6: 62-66$.

23) van den Dool, H., P. D. Kratz, 1963. J. Chromatogr., 11 : 463-471.

24) Kajiwara, T., A. Hatanaka, Y. Tanaka, T. Kawai, M. Ishihara, T. Tsuneya, T. Fujimura, 1989. Phytochemistry, $28: 636-639$.

25) Boland, W., K. Mertes, 1985. Eur. J. Biochem., $147: 83-91$.

26) Kajiwara, T., A. Hatanaka, K. Kodama, S. Ochi, T. Fujimura, 1991. Phytochemistry, 30 : $1805-1807$.

27) Whitaker, J. R., 1976. Adv. Food Res., 22: 73-133.

28) Nakajima, K., A. Uchida, Y. Ishida, 1989. Nippon Suisan Gakkaishi, 55 : 689-695.

29) Hofbauer, B., F. Jüttner, 1988. FEMS Microbiol. Ecol., 53 : 113-121.

30) Ohta, Y., Y. Hirose, 1967. Tetrahedron Lett., No. 22, 2073-2075.

31) Nagasampagi, B. A., L. Yankov, Sukh Dev, 1968. Tetrahedron Lett., No. 16, 1913-1918.

32) Suzuki, M., N. Kowata, E. Kurosawa, 1981. Bull. Chem. Soc. Jpn., 54 : 2366-2368.

33) Kajiwara, T., S. Ochi, K. Kodama, K. Matsui, A. Hatanaka, T. Fujimura, T. Ikeda, 1992. Phytochemistry, $31: 783-785$.

34) Devon, T. K., A. I. Scott, 1972. In “Handbook of Naturally Occurring Compounds Vol. II Terpenes”, p. 55184, Academic Press, New York.

35) Nabeta, K., Y. Aoki, H. Yada, Y. Ara, S. Kurano, H. Okuyama, M. Miyake, 1990. In "Flavors and Off-Flavors” (ed. by Charalambous, G.), p. 641-657, Elsevier Science Publishers, Amsterdam.

36) Charlwood, B. V., K. A. Charlwood, J. Molina-Torres, 1990. In "Secondary Products from Plant Tissue Culture" (eds. by Charlwood, B. V., M. J. C. Rhodes), p. 167-200, Clarendon Press, Oxford.

\title{
《和文要約》
}

\author{
海産褐藻へラヤハズからのプロトプラストの揮発性成分 \\ 藤村太一郎* ・川合哲夫*・梶原忠彦** ・ 石田祐三郎*** \\ *塩野香料 (株) 綜合研究所 \\ ${ }^{* *}$ 山口大学農学部応用生物化学科 \\ ***京都大学農学部水産学科
}

海産褐藻アミジグサ科へラヤハズからのプロトプラストによる揮発性成分は, 細胞を生きたままで培養し ながら抽出する閉環式へッド・スペース (CLHS) 法, GC および GC-MSによって分析し，母藻体のそれ と比較した。 それらの両者は, 共にほぼ共通の揮発性成分をもち，なかでも主要な特徵的成分のディクティ オプテレン類は, CLHS 法により PESI 培地中に放出されていることが確認された.このことは, この化 合物群が藻体そのものに起源をもち，その表面に付着する微小生物由来ではないことを示した。一方，ジプ ロピルジスルフィドは，プロトプラストのみに，キュベノールは，母藻体のみにみいだされた。すなわち， プロトプラスト化は，海藻の揮発性成分を研究する上で有用な手法であることが示唆された. 